\title{
New insights into the innate immune defences of the equine endometrium: in situ and in vitro expression pattern of beta-defensin
}

\author{
Sandra Schöniger, Denny Böttcher, Tobias Theuß, Hilke Gräfe and Heinz-Adolf Schoon \\ Institute of Pathology, Faculty of Veterinary Medicine, Leipzig University, Leipzig, Germany
}

\begin{abstract}
Summary: Equine endometrial diseases are a frequent cause of subfertility causing financial loss. Degenerative and inflammatory diseases are often associated with alterations of the innate immunity and beta-defensin has been identified within the equine endometrium. The aim of this study was to further characterize the expression of beta-defensin protein within in the equine endometrium by immunohistochemistry. For in situ investigations, endometrial samples were collected from 26 mares once at different stages of the oestrus cycle and from 3 mares repeatedly during the same oestrus cycle (days $0,5,10,13,16,19$ and 21 ; day 0 is defined as ovulation day). In vitro examinations were performed on cultured epithelial cells obtained from endometrial specimens of 15 mares. The following results were obtained: Endometrial tissue sections of the 26 mares were either without pathological alterations $(n=3)$ or showed varying degrees of endometritis, endometrosis and/or angiosclerosis. Beta-defensin protein was mainly expressed within the cytoplasm of epithelial cells lining the luminal surface (100\%, 26 mares) and glandular ducts (69\%, 18 mares) and rarely within the nucleus of these cell populations (8\% and $19 \%$, respectively). The vast majority of cells showed either a cytoplasmic or a nuclear immunostaining. A simultaneous cytoplasmic and nuclear immunoreaction within the same cell was seldom observed ( 3 mares, up to $1 \%$ of the analyzed cells). Mid and basal glands without endometrosis were rarely immunopositive (nuclear immunostaining: 5 mares; cytoplasmic labelling: 1 mare). In contrast, endometrotic glands often contained small to moderate numbers of epithelial cells with a cytoplasmic immunosignal (15 of 19 cases; $79 \%$ ). In regard to the repeatedly collected biopsies of three mares, the percentage of immunopositive cells and the calculated immunoreactive scores were highly variable over the course of the oestrus cycle and between individual mares. In regard to cultured endometrial epithelial cells ( $n=15$ mares), a positive beta-defensin immunosignal was observed in almost all cells (97\% of 521 analyzed cells) and was mainly located solely within the cytoplasm (76\% of the analyzed cells), less frequently within the cytoplasm and nucleus (17\%) and rarely only within the nucleus (4\%). These results lead to the following conclusions: the antimicrobial peptide beta-defensin can be detected within the equine endometrium, the almost complete lack of beta-defensin immunostaining of unaltered glands could predispose to bacterial colonization of glandular lumina, the frequent beta-defensin immunoreaction of endometrotic glands indicates their functional alteration also in regard to the synthesis of beta-defensin, the variations in regard to the beta-defensin immunostaining between individual mares suggest a complex regulation of the beta-defensin expression, possibly under the influence of genetic factors, the beta-defensin immunostaining of cultured epithelial cells is similar to the in situ situation and therefore the cell culture system may be used to examine pathophysiological mechanisms that modulate the beta-defensin expression within equine endometrial epithelial cells. In particular, further studies should investigate if an association exists between the beta-defensin expression patterns within the endometrium and the susceptibility of a mare to develop endometritis and/or endometrosis.
\end{abstract}

Keywords: endometrium / epithelial cells / tissue sections / cell culture / beta-defensin / immunohistochemistry / innate immunity / mare

Citation: Schöniger S., Böttcher D., Theuß T., Gräfe H., Schoon H.-A. (2016) New insights into the innate immune defences of the equine endometrium: in situ and in vitro expression pattern of beta-defensin. Pferdeheilkunde 32, 4-14

Correspondence: Dr. Sandra Schöniger, Institute of Pathology, Faculty of Veterinary Medicine, Leipzig University, An den Tierkliniken 33, 04103, Leipzig, Germany. E-Mail: sandra.schoeniger@vetmed.uni-leipzig.de

\section{Introduction}

Subfertility of mares can result in substantial financial losses for the horse breeding industry (Woolcock 1980, LeBlanc and Causey 2009). It is most commonly attributed to endometrial diseases, i.e. inflammatory (suppurative or non-suppurative endometritis) and degenerative alterations (endometrosis, angiosclerosis) as well as glandular differentiation disorders (Schoon et al. 1997, 1999, LeBlanc and Causey 2009, Lehmann et al. 2011). Only acute suppurative endometritis can already be diagnosed by routine gynaecological examination (Schoon et al. 1992, 1997, LeBlanc and Causey 2009); causes are bacterial infections and/or inflammation after mating or insemination (Schoon et al. 1992, 1997, LeBlanc and Causey 2009). The definitive diagnosis of non-suppurative endometritis, endometrial degenerative diseases and/or maldifferentiation, however, requires the histopathological examination of an endometrial biopsy (Schoon et al. 1992, 1997,
1999). The underlying cause of non-suppurative endometritis remains often uncertain; in these cases only nonspecific treatment can be performed (Schoon et al. 1997). Endometrosis and angiosclerosis represent irreversible degenerative alterations (Schoon et al. 1997). The initiating factor of endometrosis is still uncertain (Hoffmann et al. 2009a, Buczkowska et al. 2014). Endometrial maldifferentiation is either evoked by hormonal imbalances or represents a spontaneous condition of uncertain aetiology, it can be reversible (Klug et al. 1997, Schoon et al. 1999, Ellenberger et al. 2002). The concurrent presence of several of these alterations may be observed, in particular in elderly mares.

The innate immunity represents the body's intrinsic resistance against infections and stimulates the adaptive immune system (Medzhitov and Janeway 2000, Linde et al. 2008). Its molecular components include pattern recognition receptors, e.g. 
Toll-like receptors (TLRs), various antimicrobial peptides including defensins as well as chemokines and cytokines (Bruhn 2009, Bruhn et al. 2011, Turner et al. 2012). Besides their antimicrobial activity, defensins fulfil several additional functions, i.e. they act as intracellular signalling molecules, activate TLRs and cover the surface of spermatozoa preventing their immunological destruction (Hollox et al. 2008).

In recent years, it has been recognized that the altered expression or activation of molecules of the innate immunity including defensins can contribute to the pathogenesis of inflammatory or degenerative diseases within different organ systems including mucous membranes and the reproductive tract (Tlaskalová-Hogenová et al. 2004, Hollox et al. 2008, Kannaki et al. 2011, Gersemann et al. 2012, Lafyatis and Farina 2012).

The aim of this study is to further characterize and compare the expression pattern of beta-defensin (BD) protein within equine endometrial cells in situ (tissue sections of the healthy and diseased endometrium) and in vitro (cell culture). Results of this study will 1) provide further information about the expression of $B D$ protein within the equine endometrium under physiological and pathological conditions and 2) show if the cell culture system can be used as a suitable in vitro model to decipher the direct influence of physiological or pathological stimuli on the expression of BD protein within equine endometrial epithelial cells. This will expand the basic knowledge in regard to pathophysiological aspects of innate immune mechanisms within the equine endometrium.

\section{Materials and Methods}

In situ expression of $B D$ protein within the healthy and diseased equine endometrium

Mares and endometrial tissue samples

From 26 adult mares one endometrial tissue sample was examined that was either collected during post mortem examination $(n=10)$ or received as biopsy submitted for routine histological examination and prognostication of fertility. To check for a possible oestrus cycle dependent regulation of the expression of BD protein, from three adult Warmblood mares (Nos. $1-3)$ repeated biopsies $(n=7)$ were collected during the course of the same endometrial cycle (days $0,5,10,13$, 16,19 and 21 ; day 0 is defined as the day of ovulation). These mares were 4 (No. 1) and 10 (No. 2) years of age; for mare No. 3 the age was unknown.

Tissue processing

Tissue samples were fixed in $4 \%$ buffered formalin for $24 \mathrm{hrs}$ and embedded in paraplast. The further processing for histopathological and immunohistological evaluation was performed as detailed by Schöniger et al. (2013).

\section{Histological examination}

The functional morphology of endometrial glands as well as the presence of endometrial alterations, i.e. endometritis, endometrosis, angiosclerosis and/or glandular maldifferentiation was determined (Schöniger et al. 2013).
Immunostaining for the detection of BD protein

Immunohistochemistry was performed using anti-human beta-defensin-2 (1:500, Biologo, Kronshagen, Germany) as primary antibody. The peroxidase-antiperoxidase (PAP) method and 3,3-diaminobenzidine-tetrahydrochloride as chromogen were applied. Methodical details are described by Schöniger et al. (2013).

Further characterization of the BD immunosignal of endometrial epithelial cells

Per histological section, the immunostaining of each of the four different epithelial cell populations was analyzed separately, i.e. the epithelium of the luminal surface, glandular ducts, mid glands and basal glands: Digital images were taken from three representative areas by the use of an S Plan Apo $40 \times$ objective and an Olympus $\mathrm{BH} 2$ microscope equipped with an Olympus DP12 camera. In regard of each of these four epithelial cell populations, all epithelial cells within the three representative areas were examined; numbers of investigated cells for one particular cell population varied between 100 and 170 cells. The percentages of immunopositive and immunonegative cells were calculated by the use of image analysis (Schöniger et al. 2013), and the subcellular location of the immunosignal, i.e. cytoplasmic and/or nuclear, was recorded. For each cell with a cytoplasmic immunoreaction, the degree of the immunostaining was evaluated as mild, moderate or marked and the immunoreactive score (IRS) was determined according to Özgen et al. (2002).

Comparison of the BD immunosignal of glands with and without endometrosis

Within endometrial tissue sections of mares with endometrosis $(n=19)$, epithelial cells of endometrotic mid and basal glands were evaluated separately as described above. For each of these mares, numbers of immunopositive cells and the IRS of endometrotic and non-endometrotic glands were compared. Evaluated endometrotic glands were further classified as those with active, inactive or combined active/inactive fibrosis according to the morphology of the periglandular stromal cells (Hoffmann 2006). It was tested, if a possible association between an epithelial cytoplasmic immunostaining and the presence/absence of active fibrosis exists.

Expression of BD protein within cultured equine epithelial cells

Mares and endometrial tissue samples

Epithelial cell cultures $(n=17)$ were obtained from endometrial tissue of 15 adult mares. Twelve cell cultures were prepared from biopsy samples; eight biopsies were collected during the physiological breeding season and four during the winter anoestrus. The remaining endometrial tissue was received from euthanized mares submitted during the breeding season for a post mortem examination (Böttcher 2011 , Theuß 2011). Endometrial tissue samples showed a secretory or proliferative morphology of endometrial glands, a transition between both functional stages or glandular inactivity (samples collec- 
ted during the winter anoestrus). Four endometria were without endometritis or endometrosis, whereas the remaining tissue samples displayed varying degrees of endometrosis and three an additional endometritis (Böttcher 2011, Theuß $2011)$. After their isolation from the tissue, endometrial epithelial cells were seeded on MillicellÒ PET membrane inserts and cultured until their confluent growth as described elsewhere (Böttcher 2011 , Theuß 2011). Subsequently, cell cultures were fixed in $4 \%$ buffered formalin for 24-48 hrs, embedded within paraplast, sectioned with a microtome $(3 \mu \mathrm{m})$ and placed on slides. Sections were stained with haemalum and eosin (Böttcher 2011, Theuß 2011).

Immunhistochemistry for the detection of BD protein

The slides of the epithelial cell cultures of each mare were immunostained for the detection of BD protein as described above (Schöniger et al. 2013).

Further characterization of the BD immunosignal of cultured endometrial epithelial cells

From each immunostained cell culture, digital images of three representative areas were taken (S Plan Apo 40x objective of an Olympus $\mathrm{BH} 2$ microscope equipped with an Olympus DP26 camera). Cells within these representative areas were analyzed in regard to their cytomorphological and immunocytochemical features. They were subclassified in regard to their growth pattern (monolayer and/or multilayer) and their cellular morphology according to the scheme established by Böttcher (2011). Epithelial cells within a monolayer were either ovoid to polygonal (cell type 1), spindle-shaped (cell type 2) or cuboidal to columnar (cell type 3); those within a multilayer showed an ovoid to polygonal shape (cell type M) (Böttcher 2011 ). The subcellular location of the immunosignal (cytoplasmic and/or nuclear) was recorded, and the percentage of immunolabelled cells was calculated. In regard to the latter only cells with the presence of the nucleus within the examined sections were considered.

\section{Results}

In situ expression of BD protein within the healthy and diseased equine endometrium

Endometrial tissue samples of the 26 adult mares that were collected once during the course of the endometrial cycle: Mares were 4 to 20 years of age, the age of three mares was unknown; one mare was reportedly more than 10 years old. Tissue samples varied in regard to the functional morphology of endometrial glands (secretory: $n=10$; proliferative: $n=10$; transition stages: $n=4$ or maldifferentiation: $n=2)$. A complete lack of endometrial alterations was observed in 3 mares. The remaining mares had one or several endometrial diseases, i.e. mild or moderate endometritis $(n=11)$, mild or moderate endometrosis $(n=19)$ and/or mild, moderate or marked angiosclerosis $(n=20)$. In regard to the BD immunostaining, the following observations were made (Figs. 1 and 2): Endometrial tissue samples of all 26 mares displayed a positive cytoplasmic immunostaining of the surface epithelium; the percentage of these immunopositive cells varied between 3-97\% and the IRS ranged from 0.03-7.3. The majority of mares (18 of 26) had also a positive cytoplasmic immunolabelling of glandular ducts within 4-91\% of investigated epithelial cells (IRS: 0.06-5.13). Only one mare displayed a positive cytoplasmic staining in the epithelial cells of non-endometrotic mid glands $150 \%$ of the analyzed cells, IRS $=1.3)$. In all investigated mares, the epithelium of nonfibrotic basal glands lacked a positive cytoplasmic immuno-

\begin{tabular}{|l|l|l|l|l|}
\hline Immunoreaction & Surface epithelium & Glandular ducts & $\begin{array}{l}\text { Non-endometrotic } \\
\text { mid glands }\end{array}$ & $\begin{array}{l}\text { Non-endometrotic } \\
\text { basal glands }\end{array}$ \\
\hline Total immun oreactivity & \begin{tabular}{l}
$100 \%(n=26)$ \\
\cline { 2 - 5 }
\end{tabular} & $77 \%(n=20)$ & $23 \%(n=6)$ & $4 \%(n=1)$ \\
\hline $\begin{array}{l}\text { Cases with solely } \\
\text { Cytoplasmic staining }\end{array}$ & $\begin{array}{l}92 \%(n=24) \\
\text { (n) }\end{array}$ & $58 \%(n=15)$ & $4 \%(n=1)$ & $0 \%(n=0)$ \\
\hline $\begin{array}{l}\text { Cases with solely } \\
\text { nuclear staining }\end{array}$ & $0 \%(n=0)$ & $8 \%(n=2)$ & $19 \%(n=5)$ & $4 \%(n=1)$ \\
\hline $\begin{array}{l}\text { Cases with concurrent } \\
\text { cytoplasmic and } \\
\text { nuclear staining }\end{array}$ & $8 \%(n=2)$ & $11 \%(n=3)$ & $0 \%(n=0)$ & $0 \%(n=0)$ \\
\hline
\end{tabular}

Fig. 1 Immunohistochemical detection of beta-defensin within epithelial cells of equine endometrial tissue samples obtained once during the course of the oestrus cycle. A positive cytoplasmic immunolabelling of luminal epithelial cells is observed within tissue sections of all mares $(n=26)$. The majority of these cases $(69 \%, n=18)$ also contain glandular ducts lined by epithelial cells with a positive cytoplasmic immunostaining. In comparison, a cytoplasmic immunosignal within epithelia of non-endometrotic mid glands is only present in one mare, whereas non-endometrotic basal glands of all cases are negative for the detection of a cytoplasmic staining. Examined sections of all mares display seldom a nuclear immunostaining of epithelial cells.

Immunhistochemischer Nachweis von beta-Defensin in equinen endometrialen Gewebeproben, die einmal während des endometrialen Zyklus entnommen wurden. In den untersuchten Gewebeschnitten aller Stuten ( $n=26)$ kann beta-Defensin imZytoplasma des luminalen Epithels nachgewiesen werden. In der Mehrzahl der Fälle (69\%,n=18) zeigen auch die Epithelien der Drüsenausführungsgänge eine zytoplasmatische Immunreaktion. Im Vergleich dazu ist ein zytoplasmatische Immunsignal in mittleren Drüsenabschnitte nur bei einer Stute und in basalen Drüsenanteilen bei keiner Stute nachweisbar. In den Gewebeproben aller Stuten liegt nur selten eine nukleäre Expression von beta-Defensin vor. 
staining. In contrast to the cytoplasmic immunostaining, a nuclear labelling of epithelial cells was seldom observed ( 6 of 26 mares). Immunopositive cells were located within the luminal epithelium in two mares $(3 \%$ and $10 \%$ of the counted cells, respectively), within glandular ducts in five mares (5-8\% of the analyzed cells), within non-endometrotic mid glands in five mares $(2 \times 2 \%, 4 \%, 13 \%$ and $32 \%$ of the investigated cells) and within non-endometrotic basal glands in one mare (11\% and $13 \%$ of the examined cells). In the two mares with glandular maldifferentiation, non-endometrotic mid and basal glands were negative for the detection of a cytoplasmic or nuclear immunostaining.

Notably, the vast majority of the examined tissue sections $(n=23)$ contained either cells with a cytoplasmic or a nuclear immunostaining. Only within the tissue sections of three mares, up to $1 \%$ of the analyzed cells displayed a simultaneous cytoplasmic and nuclear immunostaining.

There was no obvious association between the percentage of immunopositive cells within the epithelium of the luminal surface or glandular ducts or their IRS on the one hand and the age of the mares, the functional morphology of endometrial glands (secretory or proliferative) or the presence or absence of endometritis, endometrosis and/or angiosclerosis on the other hand.

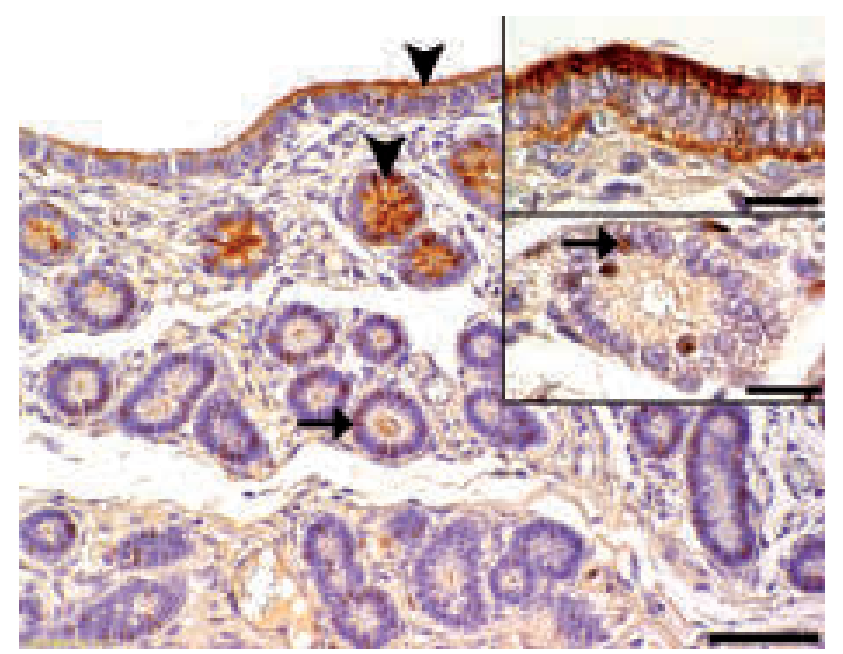

Fig. 2 Tissue section of the equine endometrium: immunhistochemical detection of beta-defensin within epithelial cells. The majority of epithelial cells lining the luminal surface and glandular ducts display a cytoplasmic immunostaining (arrowheads), whereas the epithelium of mid and basal glands lacks a cytoplasmic immunoreaction. A few epithelial cells of mid and basal glands show a nuclear immunolabelling (arrow). Bar $=100 \mu \mathrm{m}$. Upper inset: The cytoplasmic immunolabelling of the surface epithelium is depicted at a higher magnification. Bar $=25 \mu \mathrm{m}$. Lower inset: The nuclear immunostaining of scattered mid glandular epithelial cells (arrow) is shown more in detail. Bar $=25 \mu \mathrm{m}$.

Stutenendometrium: immunhistologischer Nachweis von betaDefensin in Epithelzellen. Die Mehrzahl der Epithelzellen der luminalen Oberfläche und der Drüsenausführungsgänge weist eine zytoplasmatische Immunreaktion auf (Pfeilspitzen). Epithelzellen der mittleren und tiefen Drüsenabschnitte exprimieren kein beta-Defensin im Zytoplasma. Einige dieser Zellen haben jedoch ein positives nukleäres Immunsignal (Pfeil). Messbalken $=100 \mu \mathrm{m}$. Oberes Inset: Die zytoplasmatische Immunreaktion des luminalen Epithels ist in einer höheren Vergrößerung dargestellt. Messbalken $=25 \mu \mathrm{m}$. Unteres Inset: Das nukleäre Immunsignal von einzelnen Epithelzellen mittlerer Drüsenabschnitte wird im Detail gezeigt (Pfeil). Messbalken $=25 \mu \mathrm{m}$
Repeated biopsies obtained from three adult mares over the course of the endometrial cycle: Within all examined biopsies of these three mares the functional morphology of endometrial glands was equivalent to the stage of the endometrial cycle. The repeated seven biopsies of mare No. 1 showed no pathological alterations and those of mare No. 2 mild endometrosis. In regard to mare No. 3 a mild superficial subacute suppurative endometritis was diagnosed in biopsies from days 13 and 16, and a mild superficial non-suppurative endometritis was observed within the endometrial tissue sample of day 19.

These biopsies showed similar findings (summarized below) as those observed within the endometrial tissue samples $(n=26)$ collected once during oestrus cycle. Since in all examined biopsies the nuclear immunostaining was seldom and, if present, was only observed in a few cells, solely the cytoplasmic immunostaining was further characterized. The luminal epithelium displayed always a cytoplasmic immunostaining; numbers of immunopositive cells ranged from $27-96 \%$ and the IRS varied between $0.54-7.92$. The vast majority of investigated biopsies had a positive cytoplasmic labelling of glandular duct epithelia ranging from $8-100 \%$ of the evaluated epithelial cells; the IRS varied from 0.08-9.73. Two mares, however, lacked a positive immunoreaction of glandular ducts within one biopsy sample each (mare 1: day 0; mare 3: day 5). Epithelial cells lining healthy mid and basal glands showed rarely a positive cytoplasmic immunostaining. Biopsies of mare No. 1 displayed a positve immunoreaction in non-endometrotic mid and/or basal glands at days 13-21 (1-25\% of the analyzed cells, IRS: 0.01 to 1.02). In mare No. 2 a positive labelling of healthy mid and/or basal glands was observed at days 10-16 (5-11\% of examined cells, IRS: 0.05-0.11).

Considering the expression of BD protein over the course of the oestrus cycle, the following results were obtained: Numbers of immunopositive cells and their IRS varied considerably over the course of the endometrial cycle and between the three investigated mares (Fig. 3). The repeated biopsies of each mare showed alternating phases of increase or decrease of the numbers of immunopositive cells and the IRS up to the time point with the highest/lowest numbers of immunopositive cells and the highest/lowest IRS. Epithelia of the luminal surface and gland ducts within biopsies of mare No. 2 had in general smaller numbers of immunopositive cells and a lower and less variable IRS than those within biopsies of mares Nos. 1 and 3 . There was no obvious association between the numbers of immunopositive cells or the IRS on the one hand and the stage of the endometrial cycle on the other hand.

Comparison of the BD immunosignal of unaltered and endometrotic glands: Immunostained sections of 19 mares displayed mild $(n=9)$ or moderate $(n=10)$ degrees of endometrosis of mid and basal glands. Sections of the majority of mares $(n=17)$ showed the concurrent presence of endometrotic glands with active, inactive and/or mixed active and inactive perigandular fibrosis. In sections from the remaining two mares all examined endometrotic glands were encircled by inactive stromal cells.

Due to the rare occurrence of a nuclear immunostaining in epithelia of mid and basal glands with and without periglandular fibrosis, only the cytoplasmic immunoreaction was furt- 
her characterized. Non-endometrotic mid and/or basal glands showed a positive nuclear immunolabelling in three mares (mid glands: 4, 13 and $32 \%$ of the analyzed cells, basal glands: 11 and $13 \%$ of the examined cells); in two of these mares also endometrotic glands contained a few epithelial cells with a positive beta-defensin nuclear immunostaining ( 1 and $3 \%$ of the analyzed cells).

In all but one mare endometrial cells of healthy mid and basal glands lacked a cytoplasmic immunostaining. In contrast, endometrotic glands of the majority of cases (15 of 19; $79 \%$ ) contained small to moderate numbers of BD immunopositive epithelial cells ( $1 \%$ to $34 \%$ of the investigated cells; IRS: 0.01-0.73) (Fig. 4). Notably, in one mare with a cytoplasmic immunosignal in healthy mid glands, these were lined by higher number of immunopositive cells (50\%) and

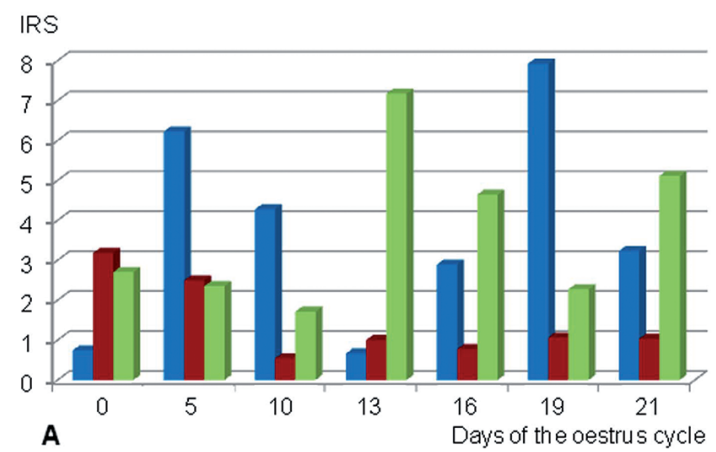

- Mare 1 - Mare 2 Mare 3

RS

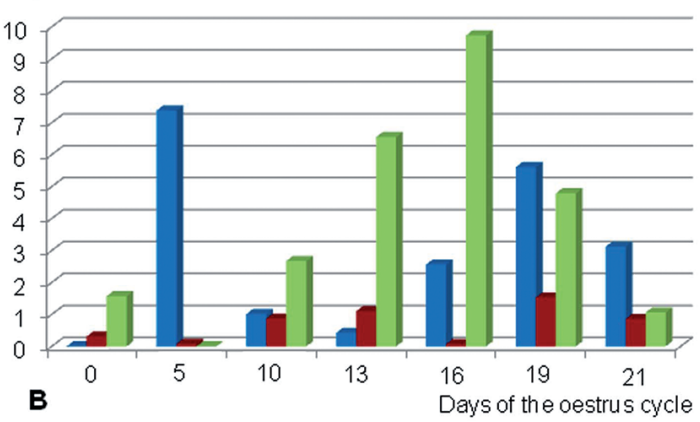

- Mare 1

- Mare 2 Mare 3

Fig. 3 Immunhistochemical expression of beta-defensin within epithelial cells of equine endometrial biopsies over the course of the oestrus cycle. From three mares, repeated biopsies were collected over the course of the oestrus cycle; day 0 is defined as ovulation day. For each mare and each examined day of the oestrus cycle, the immunoreactive scores (IRS) of the epithelium of the luminal surface (A) and glandular ducts (B) were calculated. Results show that the values of the IRS vary considerably between the examined stages of the oestrus cycle as well as individual mares. Notably, the IRS of one mare (mare No. 2) is overall lower and less variable than the IRS of the remaining two mares.

Immunhistologische Expression von beta-Defensin in Epithelzellen endometrialer Biopsien während des endometrialen Zyklus. Drei Stuten wurden wiederholt zu unterschiedlichen Stadien desselben endometrialen Zyklus bioptiert; bei Tag O handelt es sich um den Ovulationszeitpunkt. Für jede Stute und jeden untersuchten Tag des endometrialen Zyklus wurde der immunreaktive Score (IRS) separat für die zytoplasmatische beta-Defensin-Immunreaktivität des Epithels der luminalen Oberfläche (A) und der Drüsenausführungsgänge (B) berechnet. Die Ergebnisse zeigen eine hohe Variabilität der ermittelten IRS-Werte sowohl in Bezug auf die untersuchten Stadien des endometrialen Zyklus als auch die einzelnen Stuten. Auffällig ist, dass die IRS-Werte einer Stute (Nr. 2) im Allgemeinen niedriger und weniger variabel als die IRS-Werte der anderen beiden Stuten sind. had a higher IRS (1.30) than glands with periglandular fibrosis (21\% immunopositive cells, IRS: 0.73); unaltered basal glands of this mare were immunonegative and those with periglandular fibrosis contained a few epithelial cells with a cytoplasmic BD immunosignal (5\% of the analyzed cells, IRS: 0.07). There was no obvious association between the percentage of immunopositive cells or the IRS of fibrotic glands on the one hand and the degree of endometrosis or a particular morphology of periglandular stromal cells (active, inactive or combined active/inactive) on the other hand.

\section{Expression of BD protein within cultured equine epithelial cells}

Almost all evaluated cultured endometrial epithelial cells $(n=521)$ were immunopositive for the detection of BD protein (97\%). Of the immunopositive cells, the majority showed solely a cytoplasmic staining (76\%), low numbers displayed a

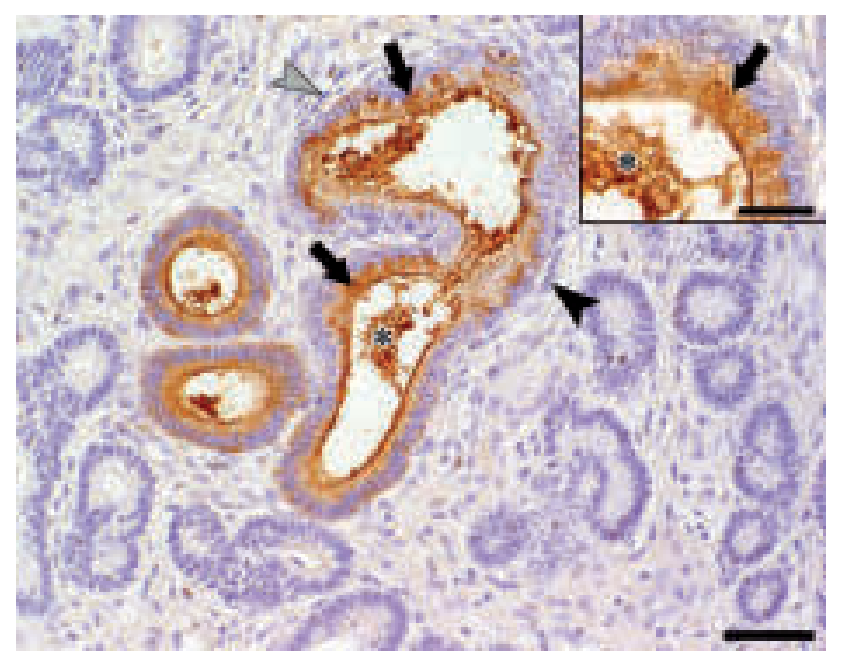

Fig. 4 Tissue section of the equine endometrium: Differences in the beta-defensin immunostaining within epithelial cells of endometrial glands with and without endometrosis. Mid glands with partially active and partially inactive endometrosis are concentrically surrounded by a moderate number of stromal cells with either ovoid hypochromatic nuclei (black arrowheads) or spindle-shaped hyperchromatic nuclei (grey arrowhead), are lined by epithelial cells with a positive cytoplasmic beta-defensin immunostaining (arrows) and contain intraluminal immunopositive secretory material (asterisk). The epithelium of the adjacent mid glands lacks a cytoplasmic immunoreaction. Scattered nuclei of glandular epithelial cells and stromal cells are immunopositive. Bar $=50 \mu \mathrm{m}$. Inset: Endometrotic mid glands with a positive immunolabelling of their epithelial cells (arrow) and intraluminal secretion (asterisk) are depicted at a higher magnification. Bar $=20 \mu \mathrm{m}$.

Equines Endometrium: Unterschiede der beta-Defensin Immunreaktivität in Epithelzellen uteriner Drüsen mit und ohne Endometrose. Mittlere Drüsenabschnitte mit teils aktiver, teils inaktiver Fibrose werden konzentrisch von einer mäßigen Anzahl an Stromazellen mit entweder ovoiden hypochromatischen Zellkernen (schwarze Pfeilspitzen) oder spindelförmigen hyperchromatischen Zellkernen (grave Pfeilspitzen) umgeben. Diese werden von Epithelzellen mit einer zytoplasmatischen beta-Defensin-Immunreaktion ausgekleidet und enthalten intraluminal immunpositives sekretorisches Material (Sternchen). Die Epithelzellen der angrenzenden nicht-endometrotischen Drüsen zeigen keine zyłoplasmatische Immunreaktivität. Ein nukleäres Immunsignal ist in vereinzelten glandulären Epithelzellen und Stromazellen detektierbar. Messbalken $=50 \mu \mathrm{m}$. Inset: Vergrößerte Darstellung einer endometrotischen Drüse, die von Epithelzellen mit einer zytoplasmatischen Immunreaktion (Pfeil) ausgekleidet wird und intraluminal immunpositives Sekret enthält (Sternchen). Messbalken $=20 \mu \mathrm{m}$ 
concurrent cytoplasmic and nuclear immunoreaction (17\%) and very few $(4 \%)$ only a nuclear immunosignal (Fig. 5). The comparative evaluation of cultured cells from endometrial samples collected during the breeding season (BS: 13 tissue samples; 417 analyzed cells) and those obtained during the winter anoestrus (WA: 4 tissue samples; 104 evaluated cells) showed that the latter contained a higher percentage of immunoreactive cells (BS: 96\%; WA 100\%), higher numbers of epithelial cells with a solely cytoplasmic immunoreaction (BS: 72\%;WA: 90\%) and fewer cells with a simultaneous cytoplasmic and nuclear immunostaining (BS: 20\%, WA: $6 \%)$; the percentage of cells with a solely nuclear immunolabelling was identical (BS and WA: 4\%). The location of immunostaining within the cell (cytoplasmic and/or nuclear) was independent of the respective cellular growth pattern (types 1-3 or type M).

\section{Discussion}

This study characterizes the in situ and in vitro expression pattern of BD within equine endometrial epithelial cells. For this immunohistochemistry was elected, since this method allows, 1) to determine the epithelial cell population(s) expressing this protein, 2) to reveal the intracellular location of the protein (cytoplasmic and/or nuclear) and 3) to perform a semiquantitative analysis of the protein expression. Subsequently, data obtained from different tissue samples can be compared with each other to check for oestrus cycle or disease related modifications of the protein expression pattern.

To obtain a semiquantitative measurement of the protein expression, in addition to the percentage of immunopositive cells, the IRS was determined. Since the latter is calculated under consideration of the percentage of immunopositive cells as well as their staining intensity (Özgen et al. 2002), it more precisely reflects the total intracellular amount of a secretory protein than the calculation of solely the percentage of immunolabelled cells.

In situ expression of $B D$ protein within the healthy and diseased equine endometrium

The presence of BD transcripts (Schöniger et al. 2013) together with the detection of $\mathrm{BD}$ protein within equine endometrial epithelial cells of the healthy and diseased endometrium as well as during all stages of the endometrial cycle indicates its constitutive expression within these cells. It can, however, not completely be ruled out that an uptake of secreted BD protein contributes to the cellular immunostaining (Nassar et al. 2012). By immunohistochemistry, beta-defensins have been also identified in epithelial cells and stromal cells of the endometrium of rats (Alan and Liman 2012) and human beings (Das et al. 2007).

The observed BD immunolabelling pattern together with findings of other investigations suggests functional differences between the different epithelial cell populations of the equine endometrium (Gerstenberg et al. 1999, Walter et al. 2001, Hoffmann et al. 2009b). In regard to the synthesis of BD protein, this function seems to be performed mainly by endometrial epithelial cells within a superficial location (luminal surface and gland ducts). The failure of glandular epithelial cells to produce significant amounts of the antimicrobial protein $\mathrm{BD}$ may predispose to persistent bacterial infections of glan-

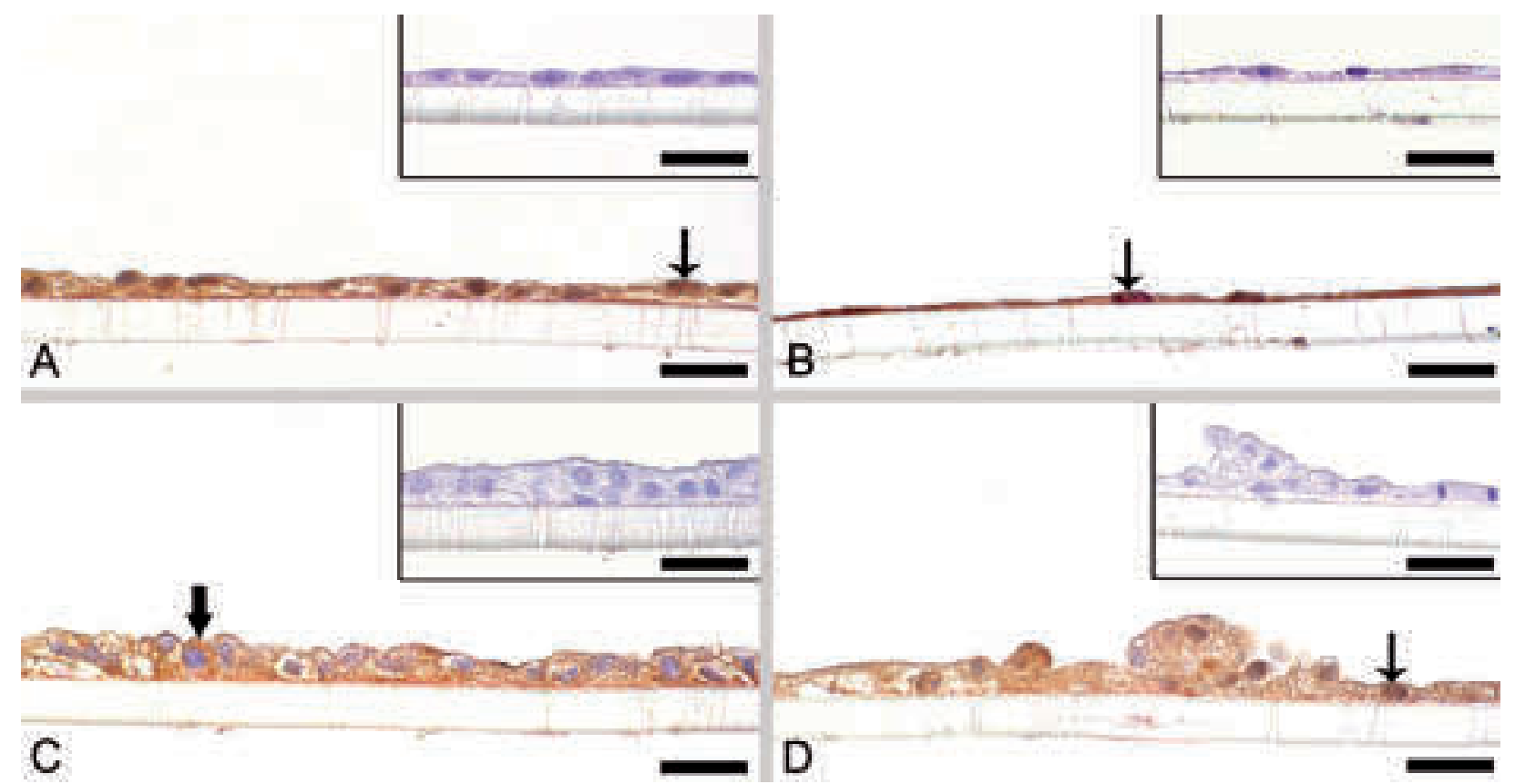

Fig. 5 Cultured epithelial cells of the equine endometrium: immunocytochemical expression of beta-defensin. A positive beta-defensin immunostaining is observed in almost all cultured epithelial cells (A-D). The immunostaining is independent of the cellular growth pattern, i.e. ovoid $(A, D)$, spindle shaped (B), cuboidal (C, D) or multilayered (D). The immunolabelling is located solely within the cytoplasm (thick black arrow) or simultaneously within the cytoplasm and nucleus (thin black arrows). Bars $=20 \mu \mathrm{m}$. Insets (A-D): The negative controls are shown. Bars $=20 \mu \mathrm{m}$. Kultivierte Epithelzellen des equinen Endometriums: Immunzytologische Expression von beta-Defensin. Eine positive beta-Defensin-Immunreaktion ist in nahezu allen kultivierten Epithelzellen nachweisbar ( $A-D)$ und ist unabhängig von dem zellulärem Wachstumsmuster, d.h. ovoid (A, D), spindelförmig (B), kubisch (C, D) oder mehrschichtig (D). Die Immunreaktion befindet sich ausschließlich im Zytoplasma (dicker schwarzer Pfeil) oder gleichzeitig in Zytoplasma und Zellkern (dünne schwarze Pfeile). Messbalken=20 um. Insets (A-D): Negativkontrollen. Messbalken=20 um. 
dular lumina. Using lectin histochemistry, a similar glycoprotein expression pattern is detected within luminal and ductular epithelium that differs from those of epithelial cells of remaining glandular portions (Walter et al. 2001). Uteroglobin, uteroferrin and glycogen are predominantly detected within the glandular epithelium (mid and basal glands), whereas uterocalin is mainly localized within the surface epithelium (Hoffmann et al. 2009b). Analysis of the proliferation marker $\mathrm{Ki}-67$ shows that the proliferative activity of the surface and glandular duct epithelium is activated during oestrus, whereas an increased proliferation of mid and basal glands occurs during dioestrus (Gerstenberg et al. 1999).

Notably, besides a cytoplasmic immunolabelling, also a nuclear expression pattern of BD protein is observed (Schöniger et al. 2013). A nuclear localization of BD has been reported in different tissues and cell populations including epithelial cells and stromal cells of the rat endometrium (Bick et al. 2007, Alan and Liman 2012).

In this study, epithelial cells with a nuclear BD expression are only present in small numbers in a few investigated endometrial tissue specimens. For this reason, the IRS is not determined for the nuclear immunostaining. The nuclear localisation of $\mathrm{BD}$ protein suggests its influence on gene transcription. It has been demonstrated that human BD-1 has sequence homologies to a nuclear loalization signal (Bick et al. 2007).

Another interesting finding is the almost complete mutually exclusive nuclear and cytoplasmic immunostaining of equine epithelial cells within examined tissue sections suggesting a negative influence of nuclear BD protein on its own transcription. This assumption is supported by findings on the expression of human BD-1 mRNA and protein in non-neoplastic and neoplastic salivary gland tissue of human beings (Pantelis et al. 2009): Neoplastic epithelial cells display a nuclear BD-1 immunostaining in association with a lower amount of BD-1 mRNA as those obtained from non-neoplastic epithelium, in which a cytoplasmic immunoreaction is observed (Pantelis et al. 2009).

Hoffmann et al. (2009b) investigate the expression of endometrial secretory proteins (uteroferrin, uteroglobin and uterocalin) over the course of the oestrus cycle in three mares and observe similar interindividual differences as those detected in the present study for BD protein. Due to the availability of corresponding serum steroid hormone concentrations, it is revealed, however, that the observed interindividual variations are at least partially associated with timely differences in the raise or decline of progesterone in these mares (Hoffmann et al. 2009b). Thus, the interindividual differences of the BD immunostaining over the course of the endometrial cycle are likely influenced by several factors, e.g. variations in serum hormone levels that occur between individual mares as well as internal or external factors that activate mechanisms of the innate immunity.

The expression of BD protein can be stimulated by the activation of TLRs as well as the certain chemokines and cytokines (Bruhn et al. 2011). Transcripts of different TLRs have been identified in the equine endometrium (Cuervo-Arango et al. 2008, Atli et al. 2010, Eaton et al. 2010, Nash et al. 2010). Likewise, different chemokines and cytokines can be produced within the equine endometrium (Nash et al. 2010, Lyle
2011). Therefore, an inflammation evoked impact on the observed epithelial BD immunostaining in mares with endometritis cannot be ruled out.

Evaluating the BD expression over the course of the endometrial cycle, one mare shows a general lower and less variable IRS than the remaining two mares; a similar finding is reported in regard to the immunohistochemical expression of calbindin (Hoffmann et al. 2009b). This suggests the existance of individual, probably genetically determined, differences in the production of $\mathrm{BD}$ and other proteins within the equine endometrium. In human beings, beta-defensin genes belong to the "copy number variable genes" and there is an association between the gene dosis and the expression level (Hollox et al. 2013). Furthermore, it has been shown that a low copy number can predispose to infectious diseases, whereas a high copy number is associated with chronic inflammatory conditions (Hollox et al. 2013). Variations in the amount of BD protein, however, could also be a sequel to the presence of different numbers of TLRs. Marked interindividual differences in regard to the expression levels of TLRs, that are partially influenced by age and environment, are described for human beings (Janssens and Beyaert 2003). In further studies, it should be investigated if certain expression levels of BD in mares can be linked to their increased susceptibility to infectious, chronic inflammatory or degenerative endometrial diseases. This would not only shed light into the pathogenesis of these diseases, but may also lead to the discovery of novel or disease specific treatment options.

The present study depicts differences in the BD protein expression pattern between non-fibrotic and fibrotic uterine glands. This is in agreement with other investigations reporting morphological and functional features in endometrotic glands that deviate from those of adjacent non-altered glands (Stewart et al. 2000, Walter et al. 2001, Lehmann et al. 2011). The aberrant expression of components of the uterine milk (e.g. uteroglobin, uterocalin, uteroferrin) by endometrotic glands likely represents an important factor of subfertility in mares with endometrosis (Hoffmann 2006, Lehmann et al. 2011 ). The obtained results on the BD expression support the assumption that fibrotic glands become independent from physiological cyclic regulatory mechanisms (Hoffmann et al. 2003, Lehmann et al. 2011 ).

Uteroglobin, however, also modulates immunological and inflammatory reactions (Mukheriee et al. 2007). This aspect together with the differences in the expression of BD protein within fibrotic and non-fibrotic glands indicates that endometrosis may also be associated with alterations of the humoral immune defence. This in turn, could result in an increased susceptibility to infection or persistent inflammation.

Moreover, epithelial cells of endometrotic glands appear to acquire characteristics of luminal epithelial cells, e.g. a cytoplasmic expression of BD protein (this study) and/or specific glycoproteins (Walter et al. 2001). Thus, endometrosis seems not only to disturb specific glandular functions, but may also impair the spatial organisation of cellular functions within the equine endometrium.

As shown in this study, the expression level/pattern of BD within the equine endometrium can be further characterized by 
the use of formalin-fixed paraffin-embedded tissue. The interpretation of obtained data, however, is limited due to the often simultaneous presence of several endometrial diseases and/or the lack of corresponding clinical data (for example serum progesterone levels). In vitro stimulation experiments on endometrial tissue or cells may assist to obtain more detailed information on the pathophysiological regulation of innate immune defence mechanisms. In regard to the equine endometrium, explant culture (Nash et al. 2008), monocultures of epithelial cells and/or stromal cells (Brady et al. 1992, Buschatz 2007, Böttcher et al. 2010, Theuß et al. 2010) as well as an epithelial-stromal cell coculture system (Lapko et al. 2014) are established.

\section{Expression of $B D$ protein within cultured equine endometrial epithelial cells}

For the present investigation, monocultures of equine endometrial epithelial cells were used (Böttcher 2011, Theuß 2011 ). This study confirms the expression of BD protein also within cultured equine endometrial epithelial cells and shows that the BD immunostaining is not influenced by the cellular growth pattern (types 1-3 or M). In general, cultured cells show BD immunostaining features that in situ are observed predominantly either in surface-associated endometrial epithelial cells (cytoplasmic immunoreactions) or mainly in glandular epithelia (nuclear immunoreaction). Similar to the in situ situation, cultured cells display mainly a cytoplasmic immunoreaction and rarely a nuclear immunostaining. In contrast to the results of the BD immunohistochemistry on tissue sections, however, cell cultures contain only very few immunonegative cells and more cells with a concurrent nuclear and cytoplasmic immunosignal. Deviations in the cellular differentiation of equine endometrial epithelial cells under in situ and in vitro conditions (monoculture) have been described previously (Böttcher 2011, Theuß 2011). These included quantitative differences in the expression of intermediate filaments (Böttcher 2011) and a solely cytoplasmic location of steroid hormone receptors in cultured cells (Theuß 2011 ). Since the observed differences in the BD immunostaining under in situ and in vitro conditions are only quantitative, the cell culture has to be regarded as suitable research tool for future studies.

\section{Conclusion}

In summary, this study further characterizes the expression patterns of BD protein within equine endometrial epithelial cells in situ and in vitro. The provided information will be an important prerequisite for the design of investigations into the pathophysiological regulation of the synthesis and secretion of $\mathrm{BD}$ protein within the equine endometrium.

\section{Acknowledgement}

The authors thank Mrs. Wipplinger, Schleinitz, Uhlemann, Pleitz and Meyer, histology laboratory, Institute of Pathology, Faculty of Veterinary Medicine, Leipzig University, for excellent technical support.

\section{References}

Alan E., Liman N. (2012) Immunohistochemical localization of beta defensins in the endometrium of rat uterus during the postpartum involution period. Vet. Res. Commun. 36, 173-185

Atli M. O., Kurar E., Kayis S. A., Aslan S., Semacan A., Celik S., Guzeloglu A. (2010) Expression of Toll-like receptors (TLRs) in the equine endometrium during the estrous cycle. Reprod. Dom. Anim. 45, 58

Bick R. J., Poindexter B. J., Buja L. M., Lawyer C. H., Milner S. M., Bhat S. (2007) Nuclear localization of HBD-1 in human keratinocytes. J. Burns Wounds 24, 7:e3

Böttcher D., Theuß T., Kappe A., Sobiraj A., Schoon H.-A., Ellenberger C. (2010) Morpho-functional characterization of equine endometrial epithelial cells in vitro - preliminary results. Pferdeheilkunde 26, 70-79

Böttcher D. (2011) Morphologisch-funktionelle Charakterisierung equiner endometrialer Epithel- und Stromazellen in Monokultur unter Einbeziehung immunzytologischer und transmissionselektronenmikroskopischer Methoden. Diss. Med. Vet. Leipzig

Brady H. A., Burghardt R. C., Evans J. W., Blanchard T. L., Vamer D. $D$. (1992) Intercellular communication in mare endometrial epithelium isolated during estrus and diestrus. J. Equine Vet. Sci. 12, 227-232

Bruhn O. (2009) Defensine des Pferdes. Duiss. agr. Kiel, pp. 1-147

Bruhn O., Grötzinger J., Cascorbi I., Jung S. (2011) Antimicrobial peptides and proteins of the horse - insights into a well-armed organism. Vet. Res. 42, 98

Buczkowska J., Kozdrowski R., Nowak M., Raś A., Mrowiec J. (2014) Endometrosis-significance for horse reproduction, pathogenesis, diagnosis, and proposed therapeutic methods. Pol. J. Vet. Sci. 17, 547-554

Buschatz S. (2007) Etablierung und Charakterisierung einer Zellkultur equiner endometrialer Epithel- und Stromazellen. Diss. Med. Vet. Leipzig

Cuervo-Arango J., Worgan H., Macías B., Nash D. (2008). Endometrial toll-like receptor 4 (TLR4) and interleukin-8 (IL-8) expression in mares resistant (RM) or susceptible (SM) to endometritis. Reprod. Dom. Anim. 43, p.75, Abstract P78. Proceedings of the 12th Annual Conference of the European Society for Domestic Animal Reproduction (ESDAR)

Das S., Vince G. S., Lewis-Jones I., Bates M. D., Gazvani R. (2007) The expression of human alpha and beta defensin in the endometrium and their effect on implantation. J. Assist. Reprod. Genet. 24, 533-539

Eaton S., Raz T., Card C. (2010) Toll-like receptors-2 and -4 in the equine endometrium during physiologic post-breeding endometritis. Anim Reprod. Sci. 121S, 96-97

Ellenberger C., Aupperle H., Bartmann C.-P., Hoppen H.-O., Schoon D., Schoon, H.-A. (2002). Endometrial maldifferentiation caused by ovarian disorders in the mare - morphological and immunohistochemical studies. Theriogenology 58, 499-502

Gersemann M., Wehkamp J., Stange E. F. (2012) Innate immune dysfunction in inflammatory bowel disease. J. Intern. Med. 271, $421-428$

Gerstenberg C., Allen W. R., Stewart F. (1999) Cell proliferation patterns in the equine endometrium throughout the non-pregnant reproductive cycle. J. Reprod. Fertil. 116, 167-175

Hoffmann C., Bazer F. W., Klug J., Allen W.R., Aupperle H., Ellenberger C., Schoon H.-A. (2003) Morpho-functional studies regarding the pathogenesis of the equine endometrosis with special emphasis on uterine secretions - preliminary results. Pferdeheilkunde 19, 666-669

Hoffmann C. (2006) Morphologisch-funktionelle Untersuchungen zur Pathogenese der equinen Endometrose unter besonderer Berücksichtigung endometrialer Proteine und Kohlenhydrate. Diss. Med. Vet. Leipzig

Hoffmann C., Ellenberger C., Mattos R.C., Aupperle H., Dhein S., Stief B., Schoon H.-A. (2009a) The equine endometrosis: New insights into pathogenesis. Anim. Reprod. Sci. 111, 261-278 
Hoffmann C., Bazer F. W., Klug J., Aupperle H., Ellenberger C., Özgen S., Schoon D., Schoon H.-A. (2009b) Immunohistochemical and histochemical identification of proteins and carbohydrates in the equine endometrium: Reaction patterns in the cycling mare. Pferdeheilkunde 25, 212-219

Hollox E. J., Barber J. C. K., Brookes A. J., Armour J. A. L. (2008) Defensins and the dynamic genome: What we can learn from structural variation at human chromosome band 8p23.1. Genome Res. 18, 1686-1697

Janssens S., Beyaert R. (2003) Role of Toll-like receptors in pathogen recognition. Clin. Microbiol. Rev. 16, 637-646

Kannaki T. R., Shanmugam M., Verma P. C. (2011) Toll-like receptors and their role in animal reproduction. Anim. Reprod. Sci. 125, 1 12

Klug E., Bartmann C.P., Schöning A., Schoon D., Schoon H.-A. (1997) Auswirkungen einer Progestagen-Langzeit-Applikation auf Sexualzyklus und Endometrium des Pferdes - Zwei Seiten einer therapeutischen Medaille. Pferdeheilkunde 13, 490-498

Lafyatis R., Farina A. (2012) New insights into the mechanisms of innate immune receptor signalling in fibrosis. Open Rheumatol. J. 6, 72-79

Lapko L., Theuß T., Böttcher D., Schoon H.-A. (2014) Establishment and characterisation of a co-culture system of primary equine endometrial epithelial and stromal cells. Reprod. Dom. Anim. 49 (Suppl. 3), 78

LeBlanc M. M., Causey R. C. (2009) Clinical and subclinical endometritis in the mare: both threats to fertility. Reprod. Dom. Anim. 44 (Suppl. 3), 10-22

Lehmann J., Ellenberger C., Hoffmann C., Bazer F.W., Klug J., Allen W.R., Sieme H., Schoon H.-A. (2011) Morpho-functional studies regarding the fertility prognosis of mares suffering from equine endometrosis. Theriogenology 76, 1326-1336

Lyle S. K. (2011) Immunological considerations. In: Equine reproduction, McKinnin A. O., Squires E. L., Vaala W. E. and Varner D. D., Eds; 2nd Ed., volume 2, Wiley-Blackwell, Chichester, West Sussex, PO19 8SQ, UK, pp. 1963-1978

Linde A., Ross C.R., Davis E.G., Dib L., Blecha F., Melgarejo T. (2008) Innate immunity and host defense peptides in veterinary medicine. J. Vet. Intern. Med. 22, 247-265

Medzhitov R., Janeway C. (2000) Innate immunity. N. Engl. J. Med. 343, 338-344

Mukheriee A. B., Zhang Z., Chilton B. S. (2007) Uteroglobin: a steroid-inducible immunomodulatory protein that founded the Secretoglobin superfamily. Endocr. Rev. 28, 707-725

Nash D., Lane E., Herath S., Sheldon I. M. (2008) Endometrial explant culture for characterizing equine endometritis. Am. J. Reprod. Immunol. 59, 105-117

Nash D. M., Sheldon I. M., Herath S., Lane E. A. (2010) Markers of the innate immune response of the mare. Anim. Reprod. Sci. 119, $31-39$

Nassar T., Akkawi S., Bar-Shavit R., Haj-Yehia A., Bdeir K., Al-Mehdi A.-B., Tarshis M., Higazi A. A.-R. (2012) Human a-defensin regulates smooth muscle cell contraction: a role for low-density lipoprotein receptor-related protein/a2-macroglobulin receptor. Blood 100, 4026-4032

Özgen S., Schoon H.-A., Aupperle H., Sieme H., Klug E. (2002) Etiopathogenesis of equine intrauterine fluid accumulation. Pferdeheilkunde 18, 594-599

Pantelis A., Wenghoefer M., Haas S., Merkelbach-Bruse S., Pantelis D., Jepsen S., Bootz F., Winter J. (2009) Down regulation and nuclear localization of human b-defensin- 1 in pleomorphic adenomas of salivary glands. Oral Oncol. 45, 526-530

Schöniger S., Gräfe H., Schoon H.-A. (2013) Beta-defensin is a component of the endometrial immune defence in the mare. Pferdeheilkunde 29, 335-346

Schoon H.-A., Schoon D., Klug E. (1992) Uterusbiopsien als Hilfsmittel für Diagnose und Prognose von Fertilitätsstörungen der Stute. Pferdeheilkunde 8, 355-362

Schoon H.-A., Schoon D., Klug E. (1997) Die Endometriumbiopsie bei der Stute im klinisch-gynäkologischen Kontext. Pferdeheilkunde $13,453-464$
Schoon H.-A., Schoon D., Wiegandt I., Bartmann C.-P., Aupperle H. (1999) "Endometrial maldifferentiation" - a clinically significant diagnosis in equine reproduction? Pferdeheilkunde 15, 555-559

Stewart F., Gerstenberg C., Suire S., Allen W. R. (2000) Immunolocalization of a novel protein (P19) in the endometrium of fertile and subfertile mares. J. Reprod. Fertil. Suppl. 56, 593-599

Theuß T., Böttcher D., Kappe A., Schoon H.-A., Ellenberger C. (2010) Establishment of a new method for isolation and culture of equine endometrial and stromal cells. Pferdeheilkunde 26, 63-69

Theuß T. (2011) Morphologisch-funktionelle Charakterisierung equiner endometrialer Epithel- und Stromazellen in Monokultur unter Einbeziehung ausgewählter zellulärer Differenzierungsmarker. Diss. Med. Vet. Leipzig

Tlaskalová-Hogenová H., Štěpánková R., Hudcovic T., Tučková L., Cukrowska B., Lodinová-Žádníková R., Kozáková H., Rossmann P., Bártová J., Sokol D., Funda D. P., Borovská D., Reháková Z., Šinkora J., Hofman J., Drastich P., Kokešová A. (2004) Commensal bacteria (normal microflora), mucosal immunity and chronic inflammatory and autoimmune diseases. Immunol. Lett. 93, 97. 108

Turner M. L., Healey G. D., Sheldon I. M. (2012) Immunity and inflammation in the uterus. Reprod. Domest. Anim. 47, Suppl. 4 402-409

Walter I., Klein M., Handler J., Aurich J.E., Reifinger M. Aurich C. (2001) Lectin binding patterns of uterine glands in mares with chronic endometrial degeneration. Am. J. Vet. Res. 62, 840-845

Woolcock J. B. (1980) Equine bacterial endometritis. Diagnosis, interpretation, and treatment. Vet. Clin. North Am. Large Anim. Pract. 2, 241-251

Erweiterte Zusammenfassung

\section{Neue Erkenntnisse bezüglich der angeborenen Immun- mechanismen des equinen Endometriums: in-situ- und in-vitro-Expressionsmuster von beta-Defensin}

Bei Stuten stellen endometriale Erkrankungen eine häufige Ursache für Fertilitätsstörungen dar und können dadurch zu substantiellen finanziellen Verlusten führen. Dabei handelt es sich um eitrige und nicht-eitrige Endometritiden, degenerative Veränderungen (Endometrose, Angiosklerose) sowie Differenzierungsstörungen der uterinen Drüsen. Die meisten der genannten Erkrankungen, mit Ausnahme von klinisch manifesten eitrigen Endometritiden, können nur anhand der histopathologischen Untersuchung eines Endometriumbioptates diagnostiziert werden. Desweiteren sind die Pathomechanismen der nicht-eitrigen Endometritis sowie der Endometrose noch weitgehend ungeklärt. Die ursächliche Beteiligung von Defekten angeborener oder erworbener immunologischer Mechanismen wird diskutiert. Zum Beispiel sind Alterationen angeborener Resistenzmechanismen häufig in die Pathogenese degenerativer und entzündlicher Erkrankungen unterschiedlicher Organsysteme involviert. Zu den angeborenen Resistenzmechanismen der Schleimhäute gehört die Synthese antimikrobieller Peptide, z.B. beta-Defensin. In einer vorherigen Untersuchung konnte die Expression von beta-DefensinTranskripten und -Protein im equinen Endometrium nachgewiesen werden. Das Ziel dieser Studie ist die nähere Charakterisierung der Expression von beta-Defensin-Protein im equinen Endometrium mittels Immunhistochemie.

Diese Untersuchungen wurden an Gewebeproben des equinen Endometriums sowie an kultivierten endometrialen Epithelzellen durchgeführt. Von 26 Stuten lag je eine endometriale Gewebeprobe vor. Diese Gewebe wurden zu unterschiedlichen Stadien des endometrialen Zyklus entnommen. Die 
übrigen drei Stuten wurden wiederholt während desselben endometrialen Zyklus bioptiert (Tage 0, 5, 10, 13, 16, 19 und 21 ; Tag 0 ist der Zeitpunkt der Ovulation). Die Zellkulturen wurden als Primärkultur aus nativen endometrialen Gewebeproben (15 Stuten) gewonnen. Die kultivierten Zellen traten in unterschiedlichen Wachstumsmustern auf (einschichtig oval bis polygonal, spindelförmig oder kubisch, bzw. mehrschichtig). Die immunhistologischen Befunde wurden mittels digitaler Bildanalyse ausgewertet. Bei den Gewebeproben und Zellkulturen wurden der prozentuale Anteil der immunreaktiven Zellen sowie die intrazelluläre Lokalisation der Immunreaktion (nukleär und/oder zytoplasmatisch) ermittelt. Die semiquantitative Auswertung der in den Epithelzellen der Gewebeproben detektierten zytoplasmatischen Immunreaktion erfolgte über die Berechnung eines immunreaktiven Scores. Die Gewebeproben wurden auch hinsichtlich des Funktionszustandes der endometrialen Drüsen und des Vorliegens von Erkrankungen ausgewertet.

Die Ergebnisse dieser Untersuchung zeigten, dass in dem equinen Endometrium (26 Stuten mit je einer untersuchten Gewebeprobe; 3 Gewebeproben ohne endometriale Veränderungen; die übrigen mit Nachweis von Endometritis, Endometrose und/oder Angiosklerose) beta-Defensin hauptsächlich in dem Zytoplasma der Oberflächenepithelien (100\%; $\mathrm{n}=26$ ) und der Epithelzellen der Drüsenausführungsgänge (69\%, 18 Stuten) nachweisbar ist. Diese Zellpopulationen hatten selten eine nukleäre Immunreaktion (8\% und 19\%), die nur in einer geringen Anzahl der analysierten Zellen vorlag (3-6\%). Epithelzellen mittlerer und tiefer Drüsenanteile zeigten fast ausschließlich eine nukleäre Immunreaktion (19\% und 4\%), nur in einem Fall fanden sich Drüsenepithelzellen mit einem immunpositivem Zytoplasma.

In Bezug auf die immunpositiven Zellen wiesen diese fast ausschließlich entweder eine zytoplasmatische oder eine nukleäre Immunreaktion auf. Das gleichzeitige Vorliegen eines nukleären und zytoplasmatischen Immunsignals in derselben Zelle wurde nur in 3 Gewebeproben beobachtet und fand sich in bis 1\% der analysierten Zellen. Zudem wurde bei Gewebeproben mit endometrotischen Drüsen $(n=19)$ überprüft, ob Unterschiede bezüglich der Expression von betaDefensin in Drüsen mit und ohne Endometrose bestehen. Mittlere und basale Drüsenabschnitte ohne Endometrose wiesen sehr selten eine zyoplasmatische beta-Defensin-Immunreaktivität vereinzelter Epithelzellen auf (1 von 19 Fällen), während diese in endometrotischen Drüsen häufig vorlag (15 von 19 Fällen; 79\%) und eine geringe bis mäßige Anzahl der auskleidenden Epithelzellen betraf. Es fand sich kein Zusammenhang zwischen dem prozentualen Anteil der immunpositiven Zellen bzw. dem immunreaktiven Score der analysierten endometrotischen Drüsen sowie dem Grad der Endometrose oder dem Aktivitätszustand der periglandulären Stromazellen (aktiv, inaktiv oder teils aktiv, teils inaktiv).

Die bei drei Stuten zu unterschiedlichen Stadien desselben Zyklus entnommenen Bioptate zeigten hinsichtlich der betaDefensin-Immunreaktivität ein mit dem der Einzelbioptate vergleichbares zelluläres Expressionsmuster, d.h. die meisten immunpositiven Zellen fanden sich im Oberflächenepithel und den Drüsenausführungsgängen und hatten eine zytoplasmatische Immunreaktivität. Eine Assoziation zwischen einem bestimmten Zyklusstand und der Anzahl der immunpositiven
Zellen bzw. der Höhe des immunreaktiven Scores konnte nicht nachgewiesen werden. Zwischen diesen drei Stuten bestanden interindividuelle Unterschiede im Hinblick auf die Anzahl der immunpositiven Zellen bzw. die Höhe des immunreaktiven Scores. Dabei wies eine Stute insgesamt eine geringere Anzahl an immunpositiven Zellen und einen niedrigeren immunreaktiven Score als die anderen beiden Stuten auf.

Nachfolgend wurde untersucht, ob die in-vitro-Expression von beta-Defensin mit den in situ an den Gewebeschnitten erhobenen Befunden vergleichbar ist. Nahezu alle untersuchten kultivierten endometrialen Epithelzellen ( $n=15$ Stuten) waren immunpositiv für den Nachweis von beta-Defensin (97\% von 521 analysierten Zellen). Das Immunsignal befand sich am häufigsten im Zytoplasma (76\% der untersuchten Zellen), weniger häufig im Zytoplasma und Zellkern (17\% der analysierten Zellen) und selten ausschließlich im Zellkern (4\% der ausgewerteten Zellen). Es konnte keine Assoziation zwischen dem Wachstumsmuster der analysierten Zellen und der intrazellulären Lokalisation der Immunreaktion festgestellt werden.

Diese Ergebnisse führen zu den folgenden Schlussfolgerungen: Das antimikrobielle Peptide beta-Defensin liegt im equinen Endometrium vor. In den Epithelzellen des Oberflächenepithels und der Drüsenausführungsgänge erfolgt mit hoher Wahrscheinlichkeit eine konstitutive Expression von betaDefensin. Das nahezu vollständige Fehlen einer beta-Defensin-Expression in den unveränderten Drüsen des equinen Endometriums könnte einen prädisponierenden Faktor für eine bakterielle Kolonisierung der endometrialen Drüsen darstellen. Der häufige Nachweis von beta-Defensin in endometrotisch veränderten Drüsen spricht dafür, dass Drüsen mit und ohne Endometrose sich hinsichtlich der Synthese bzw. Sekretion von beta-Defensin unterscheiden. Die bei den drei Stuten, von denen mehrere Bioptate im Verlauf desselben endometrialen Zyklus entnommen wurden, detektierten interindividuellen Unterschiede deuten darauf hin, dass die beta-DefensinSynthese im equinen Endometrium komplexen Regulationsmechanismen unterliegt. Als beteiligte Ursachen sollten hormonelle Einflüsse und exogene Faktoren (Infektion, mechanische Irritation) in Betracht gezogen werden. Da in den wiederholt während desselben Zyklus entnommenen Bioptaten bei einer Stute niedrigere und weniger variable Werte (prozentualer Anteil immunreaktiver Zellen, immunreaktiver Score) als bei den anderen beiden Stuten vorliegen, ist die Beteiligung einer genetischen Komponente auf die Höhe der beta-Defensin-Synthese im Endometrium in Betracht zu ziehen. In vitro (kultivierte endometriale Epithelzellen) konnte eine ähnliche beta-Defensin-Expression wie in situ (histologische Präparate des Stutenendometriums) nachgewiesen werden. Somit scheint das untersuchte Zellkultursystem ein geeignetes Invitro-Modell darzustellen, um die pathophysiologischen Regulationsmechanismen der beta-Defensin-Expression in den Epithelzellen des Stutenendometriums zu untersuchen. Insbesondere sollte überprüft werden, ob sich Endometritis-empfängliche und -resistente Stuten hinsichtlich der endometrialen betaDefensin-Expression unterscheiden bzw. ob derartige Unterschiede zwischen Stuten ohne Endometrose und solchen mit einem hohen Endometrosegrad detektierbar sind.

Schlüsselwörter: Endometrium / Epithelzellen / histologische Schnittpräparate / Zellkultur / beta-Defensin / Immunhistochemie / angeborene Immunität / Stute 